\title{
Anaerobic-Based Water Resources Recovery Facilities: A Review
}

\author{
Ahmed AlSayed, Moomen Soliman and Ahmed Eldyasti *ii \\ Department of Civil Engineering, Lassonde School of Engineering, York University, Toronto, ON M3J 1P3, \\ Canada; aalsayed@yorku.ca (A.A.); ilasimbf@yorku.ca (M.S.) \\ * Correspondence: Ahmed.eldyasti@lassonde.yorku.ca; Tel.: +1-(416)-736-2100 (ext. 31329)
}

Received: 25 June 2020; Accepted: 13 July 2020; Published: 16 July 2020

\begin{abstract}
The concept of water resources recovery facilities (WRRFs) has gained more attention as a more sustainable substitute for the conventional activated sludge-based wastewater treatment plant (CAS-WWTPs). Anaerobic treatment is advantageous due to its lower energy use, limited sludge production, and higher recovery of the soluble chemical oxygen demand (sCOD) from the received wastewater. In this article, a critical review of the proposed scheme for the anaerobic-based WRRF (An-WRRFs) is presented which is preceded with discussion of CAS-WWTPs limitations. In addition, the evolution of anaerobic treatment from being viewed as wastewater treatment plant (WWTP) to WRRF is demonstrated. It is attained that, even though anaerobic WWTPs (An-WWTPs) have simple and low energy mainline and very limited sludge handling process, its limited removal and recovery capacity have been widely reported, especially in cold weather. On the other hand, in the An-WRRF, higher energy expenditures are employed by using membranes, dissolved methane recovery unit, and primary treatment (extra sludge handling). Yet, energy recovery in the form of biogas is notably increased, as well as the removal efficiency under moderate residence times. The three key challenges to be overcome are the low value of biogas, reducing the energy use associated with membranes, and maintaining high performance in full-scale, especially in cold weather.
\end{abstract}

Keywords: water resources recovery facilities (WRRF); anaerobic treatment; dissolved methane; energy self-sufficiency; anaerobic membrane; anaerobic fluidized bed membrane bioreactor (AFMBR)

\section{Introduction}

For more than a century, conventional activated sludge (CAS) has been the most common treatment process adopted by wastewater treatment plants (WWTPs), especially in North America and Europe. Even though CAS can be considered as a matured process in terms of pollutants removal, its energy and economic deficiency has raised the need for alternative processes [1]. The energy used in WWTPs based on CAS (CAS-WWTPs) ranges from 1080 to $2160 \mathrm{~kJ} / \mathrm{m}^{3}$ [2,3]. Whereas, municipal WWTPs typically receive wastewater with total chemical oxygen demand (TCOD) of 300-800 mg/L, corresponding to energy of $4170-11,120 \mathrm{~kJ} / \mathrm{m}^{3}$. This implies that the available energy contained in wastewater (as COD) is 2-10 times higher than the energy used for its treatment. In the light of those facts, the vision for WWTPs as energy and cost-intensive facilities that its only purpose is to remove contaminants from wastewater has been reassessed.

In preference, the concept of water resources recovery facility (WRRF) was tabled. In WRRFs, wastewater is perceived as a latent source of energy and resources that are targeted to be recovered within the facility [4]. Here, it is worth pointing out that WRRFs are still meant to treat the received wastewater and meet the effluent discharge standards for different pollutants as the top priority. However, the objective is to do so in a sustainable and economically viable approach. The paradigm shift from WWTPs to WRRFs has appealed the industrial sector and lead the research into new 
dimensions. The increased number of publications about WRRF that has not peaked yet is evidence of such great industrial and academic interest. Therefore, much more attention is being paid to develop novel processes such as bioelectrochemical systems or to reconsider multiple processes like anaerobic treatment and carbon redirection through high rate systems and/or chemically enhanced primary treatment (CEPT) [3,5].

Over the past decade, distinct concepts have been proposed for the integration of the aforementioned technologies to design WRRFs. Proposed concepts can be clustered into two major groups based on the stream targeted for recovery: liquid stream and solids stream WRRFs. On one hand, solids stream WRRFs (SS-WRRFs) are closer in configuration to the existing CAS-WWTPs. In SS-WRRFs, the liquid stream is designed to densify the diluted COD concentration in the liquid stream and redirect it into the solids stream for recovery [6]. On the other hand, liquid stream WRRFs (LS-WRRFs) are built to recover COD directly within the liquid stream, while minimal sludge is produced and recovered within the solids stream [1]. Further classification for the proposed WRRFs can be carried out according to the carbon flow and key products and intermediates as shown in Figure 1. Noteworthy, a common feature in the WRRFs is that carbon recovery is no longer combined with nutrients recovery/removal [4].

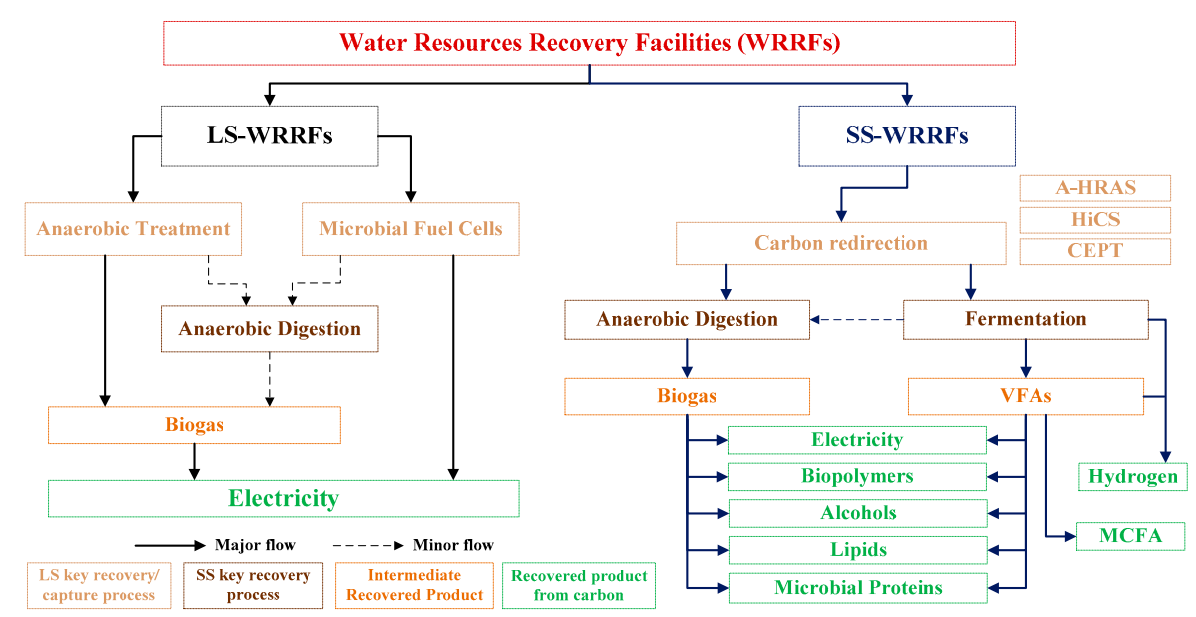

Figure 1. Water resources recovery facilities (WRRFs) classification based on the recovery stream and carbon flow. LS: liquid stream, SS: solids stream, A-HRAS: A-stage high rate activated sludge, HiCS: high rate contact stabilization, CEPT: chemically enhanced primary treatment, VFA: volatile fatty acid, MCFA: medium-chain fatty acid.

In LS-WRRFs, COD recovery is carried out directly in the liquid stream that preferably facilitates the capture of the soluble COD (sCOD), which is considered as a key limitation in SS-WRRFs [7]. By consequence, LS-WRRFs enhance the overall COD capture efficiency. Besides, LS-WRRFs have lower energy consumption since aeration is eliminated and much lower sludge volumes are generated [8].

As illustrated in Figure 1, two technologies can be employed in LS-WRRFs: anaerobic treatment and microbial fuel cells (MFCs). Nonetheless, in the case of MFCs, technology readiness level is yet to be improved (at least becomes $>7$ ) to be considered as a reliable alternative. Whereas, growing attention is being paid to anaerobic treatment as a more reliable option [9-11]. Hence, this article focuses on anaerobic treatment as a reliable option for LS-WRRFs. The aim of this review is to provide a technological update and critical discussion about the configuration of the anaerobic-based water resources recovery facilities (An-WRRFs). In accordance, the discussion commences with the CAS-WWTPs limitations in carbon recovery to clearly identify the gaps to be fulfilled by WRRFs proposed technologies. In addition, the concept of the conventional anaerobic WWTPs (An-WWTPs) is presented in order to distinguish it from the An-WRRFs and demonstrate such evolution. Thereupon, the concept of the scheme for An-WRRFs is critically reviewed including the main biological technology and the following process for dissolved methane recovery. 


\section{Conventional Activated Sludge Wastewater Treatment Plants (CAS-WWTP)}

Typically, in the CAS-WWTPs, the settable solids from the preliminary treated wastewater are removed from the influent in the primary clarifier and, subsequently, primary sludge is collected and directed toward the solids stream. As shown in Figure 2, primary treatment results in removing 28\% to $40 \%$ of the influent COD, mostly in the form of particulate COD (pCOD) [12]. Primary clarifier is followed by CAS system that consists of aeration tank and secondary clarifier. The performance of the CAS system varies according to the operational parameters; however, sludge age or solids retention time (SRT) is the most crucial parameter [13]. In the aeration tank, heterotrophs directly utilize the sCOD that has not been captured in the primary clarifier [14]. Meanwhile, bioflocculation takes place in which extracellular polymeric substances (EPS) are produced to enmesh the pCOD and microorganisms forming sludge flocs. The resulted flocs can easily settle in the secondary clarifier as it is relatively larger than individual particulates or microorganisms [15]. The settled sludge within the secondary clarifier is returned to the aeration tank to maintain high biomass concentration, while the excess sludge is transferred to the solids stream [16]. A minimum SRT of $2-5$ days is required to allow the hydrolysis and utilization of the captured COD [17]. In terms of mass balance, a COD removal efficiency as high as $96 \%$ can be achieved at SRTs longer than 3-4 days [18]. The COD removed within the CAS system is either converted into carbon dioxide (mineralization) or captured as sludge. Depending on the employed SRT and primary treatment efficiency, the COD mineralized and COD captured in the sludge ranges from $30 \%$ to $50 \%$ and from $18 \%$ to $26 \%$ of the influent TCOD, respectively $[3,12,17,18]$. Commonly, the applied SRTs on CAS-WWTPs are 10 days or longer, resulting in higher COD mineralization and limited capture [17]. The design based on long SRTs is to allow nitrification in the aeration tank and as a factor of safety to assure high removal efficiencies [19].

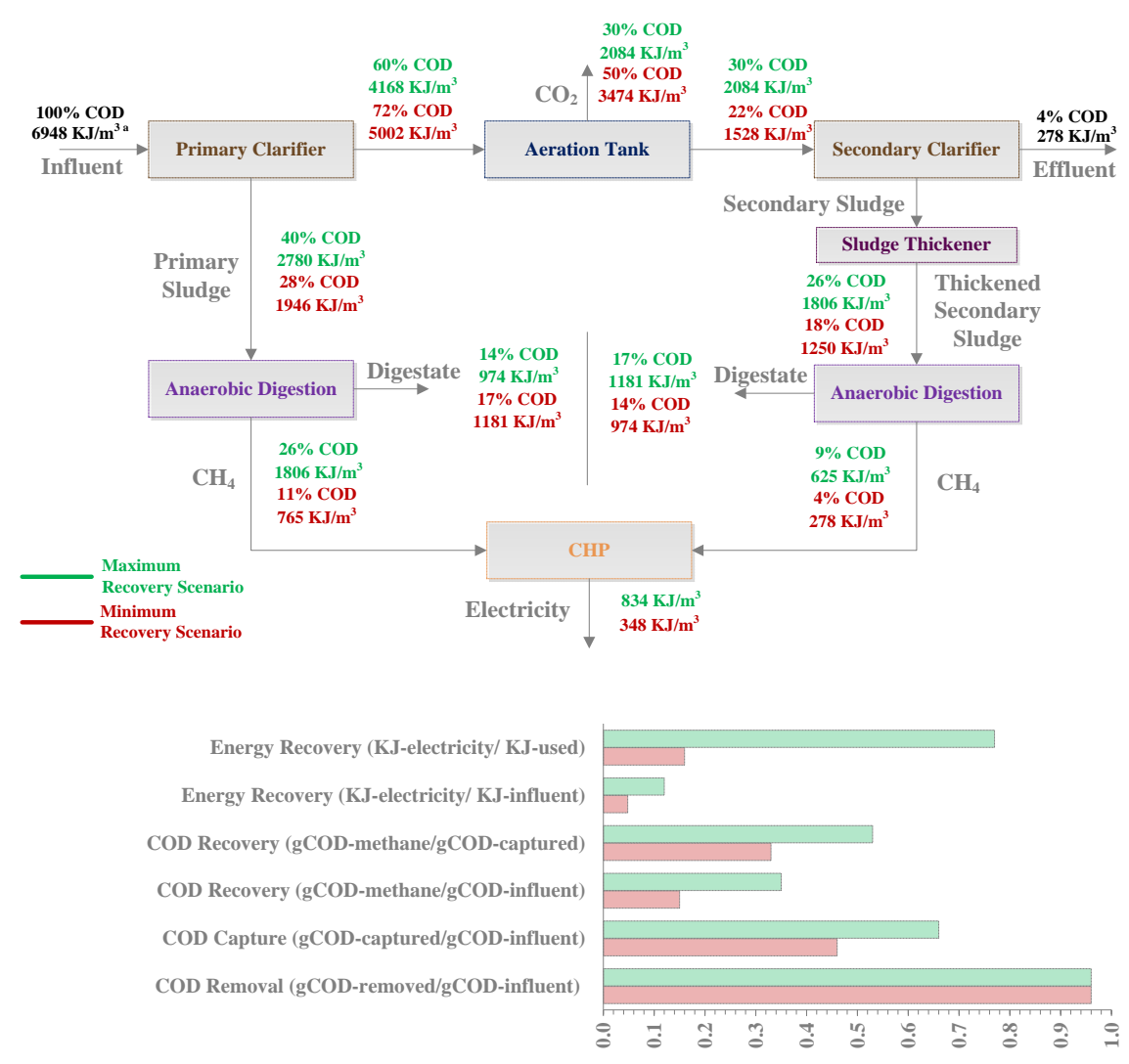

Figure 2. Maximum and minimum recovery scenarios in typical conventional activated sludge-based wastewater treatment plants (CAS-WWTPs) for chemical oxygen demand (COD) and energy balance. a: $6948 \mathrm{~kJ} / \mathrm{m}^{3}$ is based on assuming an influent with $500 \mathrm{mg}-\mathrm{COD} / \mathrm{L}$ as an average value for municipal wastewater. 
Concurrently, within the solids stream, the primary sludge and the thickened secondary sludge are digested and converted into biogas in the anaerobic digesters (AD). In addition to moisture and other impurities like hydrogen sulfide, the AD-driven biogas consists of 50-70\% methane $\left(\mathrm{CH}_{4}\right)$ and $30-50 \%$ carbon dioxide. It can be employed to generate electricity using combined heat and power (CHP) technologies [20]. Combined, the sludge captured from primary and secondary clarifiers and directed to the AD represents about $46-66 \%$ of the influent TCOD, as shown in Figure 2 . The combined conversion efficiency for the collected sludge to methane can theoretically reach 0.86 gCOD- $\mathrm{CH}_{4} / \mathrm{gCOD}$-sludge $[2,17]$. However, the actual conversion efficiencies are much lower. It has been reported that primary and secondary sludges conversion efficiencies to methane are $0.4-0.65$ and $0.2-0.35$ gCOD-CH 4 /gCOD-sludge, respectively [12,21]. As a result, the fraction of the COD recovered as methane is nearly $15-35 \%$ of the influent COD, which results in around $5-12 \%$ COD recovery in the form of electricity, given that the electricity efficiency of $\mathrm{CHP}$ technologies average at 35\% [22]. COD and energy balances for typical configuration of CAS-WWTPs are illustrated in Figure 2 assuming maximum and minimum efficiencies.

As aforementioned, it is unequivocal that the sole objective of CAS-WWTPs is pollutants removal. The adopted rationale is that processes are carried out over two separate streams: liquid and solids. Liquid stream is the major stream where raw sewage is received. It is recognized by its diluted concentrations and high flow rates. On the other hand, high concentrations are found in the solids stream that is meant for sludge management [23]. The ratio between the flow rate in both streams can be $10 \%$ at maximum [6]. The purpose of the liquid stream is pollutant removal and not to capture or recover any carbon. Recovery processes are carried out in the solids stream relying on the poorly captured COD. Whereas, electrical energy intermediated with biogas is the main recovered product from carbon. Nevertheless, solids destruction/removal is the priority in the solids stream. As depicted in Figure 2, the resulted energy recovery is only $5-12 \%$ of the available energy in the influent COD and $16-77 \%$ from the utilized energy.

By tracing the COD and energy flow, the notable COD loss within CAS-WWTPs can be broken down into four main fractions. First, the COD escaping in the effluent that ranges between $4 \%$ and $10 \%$ of the influent COD and can be considered minimal [17]. Second, the limited COD capture in the liquid stream, as $30-50 \%$ of the influent COD is mineralized in the aeration tank. The third fraction is due to the limited digestibility or methane yield from the captured sludge. It results in the loss of $30 \%$ of the influent COD as it is not completely digested to biogas and discharged with the AD digestate. Although the loss in the digestate cannot be completely eliminated, $7-14 \%$ of the influent COD can be recovered by enhancing the quality of the secondary sludge to approach primary sludge digestibility. The poor quality of the secondary sludge can be for the most part referred to the relativity long SRTs applied in CAS, which ranges from 3 to 15 days [19]. Fourth, the selection of biogas as the intermediate to produce electricity using CHP technologies results in the loss of $10-23 \%$ of the influent COD in the form of heat. As an alternative, it was proposed that biogas can be upgraded into biomethane and injected to the natural gas grid as a commodity. However, such alternative is not economically viable due to the current methane low prices [24].

Conclusively, four key limitations need to be addressed to shift WWTPs into WRRFs; (i) limited COD capture due to mineralization and process removal efficiency, (ii) sludge poor quality due to long sludge ages, (iii) the low value of biogas either in electricity generation or as a commodity, and (iv) the high energy expenditure of the CAS-WWTPs. Such high energy use can be referred to the aeration requirements and sludge handling, which are responsible for about $74 \%$ of the total energy consumption [25]. Therefore, the capacity of the anaerobic-based WRRF (An-WRRF) to lessen the COD loss, reduce its energy consumption, and enhance the energy/resources recovery in order to circumvent the four key challenges will be considered in the discussion below. 


\section{Anaerobic Wastewater Treatment Plant (An-WWTP)}

In addition to sludge digestion, anaerobic treatment systems have been applied in wastewater treatment supported by its energy savings. The key milestone led to anaerobic systems application in domestic wastewater treatment was the development of the upflow anaerobic sludge blanket (UASB) system in the early eighties of the past century [26]. UASB is designed to effectively retain the biomass and solids as aggregates or granules in the sludge blanket without carriers. The formed blanket allows extended SRTs needed for solids destruction and biogas recovery while maintaining moderate hydraulic retention times (HRT) [27]. Besides decoupling HRT and SRT, sludge blanket provides a convenient platform for intricate microbial structure that enhances reactor stability and its capacity to handle complex substrates and higher organic loading rates (OLR) [28]. The simultaneous gas production maintains sufficient biomass contact with the pollutants that eliminates the energy required for mechanical mixing [7]. In addition to UASB, diverse bioreactor configurations were studied including, but not limited to, anaerobic fluidized bed bioreactor (AFBR) and anaerobic moving bed biofilm reactor (AMBBR) [29]. Yet, UASB is distantly the most vigorous anaerobic bioreactor employed in full-scale domestic wastewater treatment [30].

The common practice of UASB in WWTPs is to be preceded only by preliminary treatment [27]. As a result, solids hydrolysis becomes the rate-limiting step and extended SRTs should be maintained for adequate solids destruction and removal efficiency [17]. It is worth pointing out that, despite its capacity to handle the solids with minimal clogging, lower pCOD fraction (or solids content) in UASB influent results in better granulation and reactor performance due to the elimination of any channeling in the sludge blanket $[31,32]$. It was reported that UASB reactors implied COD removal efficiencies average at $67.5 \%$ and range from $54 \%$ to $85 \%$ [29]. With similar ranges, another study on full-scale UASB systems in Latin America demonstrated that the COD removal efficiency ranges from 39\% to 79\% [27]. With average removal efficiency of nearly $70 \%$, UASB effluents are typically subjected to post-treatment stage to meet discharge standards [33]. Wide range of alternatives have been used as post-treatment stage, which most frequently includes trickling filters, activated sludge system, submerged aerated biofilms, dissolved-air floatation, polishing ponds, and constructed wetlands [34]. It can be observed that the post-treatment stage is energy and/or land requiring. To achieve COD removal, aerated systems are recommended as the post-treatment [27]. However, it raises the energy input at the An-WWTPs to $500-860 \mathrm{~kJ} / \mathrm{m}^{3}$ treated [34]. Regarding the sludge production, anaerobic systems are recognized by their low sludge yield. This can be explained by its microbial community that comprises very low yield and, by consequence, low sludge production. The combined bacterial yield in anaerobic systems was estimated to be 0.11 gCOD-biomass/gCOD-removed compared to about 0.6 gCOD-biomass/gCOD-removed in aerobic systems [17]. In addition, the obtained sludge does not need further stabilization and can be directed to dewatering, which saves the energy and cost needed for sludge thickening and digestion.

Following the typical flowline of preliminary treatment-UASB-post-treatment, COD recovery takes place only in the UASB. With biomass yield of $11 \%$, only $8 \%$ of the influent COD is converted into biomass. Given that average removal efficiency is $70 \%$, COD available for the conversion into biogas is $62 \%$ of the influent COD. Assuming methane content in the biogas of $70 \%$, the An-WWTPs methane conversion efficiency can be estimated to be $44 \%$ of the influent COD. However, the actual yields reported in the literature $(17 \pm 8 \%)$ are much lower than the estimated [29]. An-WWTPs energy efficiency mainly depends on the selected post-treatment technology. By using aerated systems to maintain high effluent quality, an average methane and electricity recovery of $1.64 \mathrm{~kJ}-\mathrm{CH}_{4} / \mathrm{kJ}$ used and $0.57 \mathrm{~kJ}$-electricity $/ \mathrm{kJ}$ used, respectively, can be achieved. Such efficiency has a big room of improvement if the An-WWTPs complications were to be overcome. Yet, An-WWTPs are more energy efficient than CAS-WWTPs due to their lower energy consumption, even though similar methane recovery might be obtained in both systems.

Collectively, the rationale for An-WWTPs is to combine both removal and recovery in the liquid stream, cancel the solids stream, separate the carbon and nutrients removal/recovery (in some cases 
nutrients removal is not desired when effluent used for agricultural purposes [2]), and minimize the energy use. On the upsides, it successfully achieves substantial energy savings (up to 90\%) since no aeration and mechanical mixing is needed, while sludge production is minimal. In addition, it has a lower capital cost and simpler operation scheme since primary and secondary clarifiers and ADs are no longer needed. Moreover, enhanced COD capture and recovery can be potentially attained as SCOD is recoverable and less COD is channeled to microbial growth. Here, emphasis shall be put on the wide range of COD removal efficiency and, by consequence, methane recovery as it stems the An-WWTPs key advantage [27]. For instance, COD removal efficiency for a pilot-scale UASB recently operated was reported as low as 30\% [31]. It can be said that UASB removal efficiency and methane recovery remains questionable, hard to attain at high levels, and subjected to notable variation [35]. Such susceptibility has hindered the broad spread of An-WWTPs, particularly in cold weather. Under psychrophilic conditions (Temperature $<20^{\circ} \mathrm{C}$ ), anaerobic treatment is challenged as detailed elsewhere [36]. Briefly, these challenges can be referred to complex nature of the domestic wastewater (unlike the industrial or pre-acidified wastewater), reduction in microbial kinetics (i.e., substrate utilization rates and maximum specific growth rates), and the alteration in physical and chemical properties of wastewater (i.e., viscosity, gases solubility, and soluble compounds diffusion). As a result, methane yield, COD removal, and specific methane production rates are notably declined [36]. In terms of other and less significant shortcomings, biogas is the only possible recovery product from COD. Additionally, UASB reactors require too long startup periods in order to develop functional sludge blanket. Moreover, process stability and shock load handling are major concerns for anaerobic systems. Both, long startups and shock loads handling, can be referred to the solids hydrolysis, the slow rate of the fermenters and methanogens, and its sensitivity to environmental changes such as volatile fatty acids (VFAs) higher concentration, $\mathrm{pH}$, and temperature [28]. Another critical drawback is the escaped dissolved methane (D-methane) in the effluent that reported to be $11-81 \%$ at temperatures above $25^{\circ} \mathrm{C}$, while higher values have been observed at lower temperature [35]. On top of its environmental negative effect, D-methane limits COD capture efficiency and contributes to the variation between the methane yield estimated above and the reported values as discussed before.

Combined, An-WWTPs upsides outweigh its downsides in tropical and hot weathers found in South America and Africa. As such, more than 450 UASB-based WWTPs are already installed in Latin America. In contrary, An-WWTPs implementation is hampered at water temperatures below $15^{\circ} \mathrm{C}$, which takes place under temperate climate conditions in places like North America and Europe. In low temperatures, anaerobic microbial activity is notably declined, resulting in diminishing process stability, capacity to handle shock loads, removal efficiency, and methane recovery. Moreover, escaped methane in effluent can reach up to $100 \%$ due to the increased gas solubility in lower temperatures. Unfortunately, heating the liquid stream is not feasible due to its large volumes given that more than $4000 \mathrm{~kJ}$ as heat is required to increase the temperature of $1 \mathrm{~m}^{3}$ of wastewater by $1^{\circ} \mathrm{C}$ [35].

\section{Anaerobic Water Resources Recovery Facility (An-WRRF)}

An-WWTPs are unambiguously more energy efficient than CAS-WWTPs. Auspiciously, its basic idea addresses three out of the four core limitation in CAS-WWTPs as previously illustrated. However, the process drawbacks, particularly in cold weather, necessitate further improvements in terms of its energy balance and applicability. An-WRRF and An-WWTP share the same core process, which is high-rate anaerobic reactor. Nonetheless, key modifications are introduced as pre- and post-treatment to address the reported complications. The concept for the An-WRRF was proposed by McCarty et al. [2], which was later named the low energy mainline (LEM) approach [18]. Such configuration is illustrated in Figure 3 associated with COD and energy balances.

Pursuing the LEM approach, the received wastewater is subjected to primary treatment prior to the anaerobic reactor. The primary sludge is, then, channeled to $\mathrm{AD}$ for solids reduction and biogas recovery. As a result, solids concentration in the anaerobic reactor influent is considerably reduced as well as the TCOD and the OLR. This would result in two contrary effects on the anaerobic reactor. 
On one side, solids reduction may enhance process performance by reducing the hydrolysis negative effect and blanket channeling by the solids [37]. In addition, some other limitations associated with high solids content in the influent are eliminated such as nutrients removal hindrance and sludge production increase, which may lead to the occupation of inerts in the sludge blanket [38]. On the other hand, diluted COD concentration has been always a limiting factor for anaerobic treatment, as shown in Table 1 [17]. It was reported that the COD removal efficiency did not exceed $54 \%$ for pre-settled sewage sludge (influent average, TCOD $=391 \mathrm{mg} / \mathrm{L}, \mathrm{sCOD}=291 \mathrm{mg} / \mathrm{L}$ ) [39]. A more recent study showed slightly enhanced removal efficiency of $55-65 \%$ for CEPT-treated domestic wastewater (influent average, TCOD $=140 \mathrm{mg} / \mathrm{L}$ and sCOD $=115 \mathrm{mg} / \mathrm{L}$ ). However, these results were not accompanied by granulation and methane recovery results [40]. At lower temperature but with pre-hydrolyzed wastewater, as presented in Table 1, the maximum attained removal efficiency and methane recovery was $65 \%$ and $37 \%$ at influent TCOD and sCOD of 281 and $100 \mathrm{mg} / \mathrm{L}$, respectively [41]. The attained poor performance is mainly referred to as the slow microbial activity for methanogens resulting in poor granulation and limited substrate uptake at low OLRs [37]. To increase the OLR in diluted wastewater, higher volumetric loading rates can be applied, resulting in higher upflow velocities. Though solids/biomass washout and expanded beds deteriorate the removal efficiency [32].

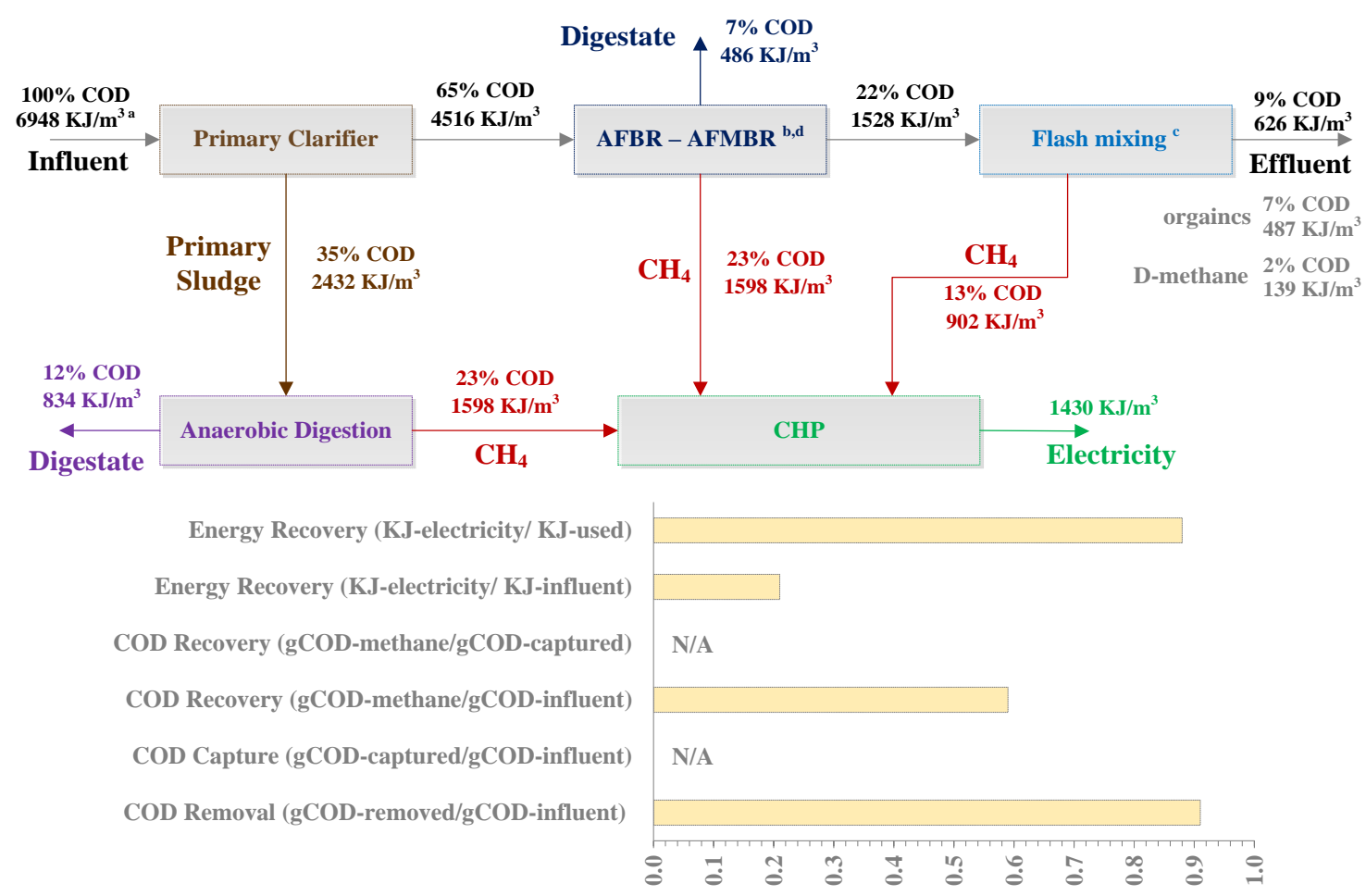

Figure 3. Expected COD and Energy balance for An-WRRF. a: $6948 \mathrm{~kJ} / \mathrm{m}^{3}$ is based on assuming an influent with $500 \mathrm{mg}-\mathrm{COD} / \mathrm{L}$ as an average value for municipal wastewater, b: values obtained according to Reference [42], c: values obtained according to Reference [43], d: 13\% of the influent COD is converted to carbon dioxide, sulfur, and losses, N/A: Not Applicable.

Alternatively, anaerobic membrane bioreactor (AnMBR), in which membrane filtration is integrated internally or externally with anaerobic reactor, is suggested as the high-rate anaerobic treatment reactor. Using membranes, longer SRTs can be maintained that attenuates the negatives of relying on the slow-growing methanogens [33]. Such benefit is mandatory at cold temperatures or diluted COD concentrations of the pre-settled influent [7]. Additionally, anaerobic membrane would serve as a post-treatment unit in which COD removal efficiencies above $95 \%$ can be attained [1]. Besides, membranes as liquid/solids separators are advantageous due to their small footprint and the poor settleability of the anaerobic solids [2]. Apparently, the integration of primary clarifier 
and membrane filtration as pre- and post-treatment for the high-rate anaerobic reactor is a very prominent strategy as high effluent quality, high energy production, and minimum energy use can be attained. Elucidating this, a review study on pilot-scale anaerobic bioreactors shows that energy expenditure in AnMBR to treat pre-settled wastewater is lower than raw wastewater due to the difference in solids content [44]. On the other hand, the addition of membrane mitigates the negative effects associated with diluted concentrations. Meanwhile, the methane recovery from primary sludge ( 0.65 gCOD- $\mathrm{CH}_{4} / \mathrm{gCOD}$-removed) is similar or higher than methane recovery from raw wastewater [21,29].

Table 1. The average results of selected studies of anaerobic systems for An-WWTPs and An-WRRFs.

\begin{tabular}{|c|c|c|c|c|c|c|c|}
\hline Study & Reactor & Influent Type & $\begin{array}{c}\mathrm{TCOD}_{\text {in }} \\
(\mathrm{mg} / \mathrm{L})\end{array}$ & $\begin{array}{l}\mathrm{sCOD}_{\text {in }} \\
(\mathrm{mg} / \mathrm{L})\end{array}$ & $\begin{array}{l}\text { Temp. } \\
\left({ }^{\circ} \mathrm{C}\right)\end{array}$ & $\begin{array}{c}\text { TCOD } \\
\text { Removal (\%) }\end{array}$ & $\mathrm{CH}_{4}$ Recovery (\%) * \\
\hline [39] & EGSB & Pre-settled WW & 391 & 291 & 13.2 & $<54$ & NR \\
\hline [40] & UASB & $\begin{array}{l}\text { CEPT treated } \\
\text { domestic WW }\end{array}$ & 140 & 115 & 33 & $55-65$ & NR \\
\hline [41] & UASB & $\begin{array}{c}\text { Pre-hydrolyzed } \\
\text { WW }\end{array}$ & 281 & 100 & $14-21$ & 65 & 36 \\
\hline [42] & $\begin{array}{l}\text { Single Stage } \\
\text { AFMBR }\end{array}$ & $\begin{array}{c}\text { primary-settled } \\
\text { domestic WW }\end{array}$ & 282 & 112 & $15-20$ & 94 & 39 \\
\hline [42] & $\begin{array}{c}\text { two stage } \\
\text { AFBR-AFMBR }\end{array}$ & $\begin{array}{l}\text { primary-settled } \\
\text { domestic WW }\end{array}$ & 198 & 116 & $11-15$ & 90 & 36 \\
\hline [43] & AMBBR & Synthetic WW & 400 & NR & 30 & 80 & 18.3 \\
\hline [45] & AnMBR ** & Municipal WW & 892 & 501 & 18 & 87 & $\begin{array}{c}0.21 \mathrm{Nm}^{3} \mathrm{CH}_{4} / \mathrm{kg} \\
\mathrm{COD}_{\text {removed }}\end{array}$ \\
\hline [46] & AnMBR *** & Municipal WW & 978 & 610 & 18 & 90 & $0.2 \mathrm{~L} \mathrm{CH}_{4} / \mathrm{g} \mathrm{TCOD}_{\mathrm{fed}}$ \\
\hline [47] & $\begin{array}{c}\text { two stage } \\
\text { AFBR-AFMBR }\end{array}$ & Synthetic WW & 513 & 513 & 35 & 99 & $\begin{array}{c}4.11 \mathrm{~mol} \mathrm{CH}_{4} / \mathrm{m}^{3} \\
\text { wastewater }\end{array}$ \\
\hline [48] & $\begin{array}{l}\text { Single Stage } \\
\text { AFMBR }\end{array}$ & Synthetic WW & 200 & 200 & 25 & $94-96$ & NR \\
\hline [48] & $\begin{array}{c}\text { two stage } \\
\text { AFBR-AFMBR }\end{array}$ & Synthetic WW & 200 & 200 & 25 & $94-97$ & NR \\
\hline [49] & $\begin{array}{l}\text { Single Stage } \\
\text { AFMBR }\end{array}$ & Domestic WW & 320 & NR & 35 & 75.8 & 45.2 \\
\hline [50] & $\begin{array}{c}\text { two stage } \\
\text { AFBR-AFMBR }\end{array}$ & $\begin{array}{c}\text { Settled raw } \\
\text { municipal WW }\end{array}$ & 809 & 70 & 23 & 97 & NR \\
\hline [50] & $\begin{array}{l}\text { Single Stage } \\
\text { AFMBR }\end{array}$ & $\begin{array}{c}\text { Settled raw } \\
\text { municipal WW }\end{array}$ & 809 & 70 & 23 & 97 & NR \\
\hline
\end{tabular}

EGSB: expanded granular sludge bed, WW: wastewater, NR: Not reported, ${ }^{*}:$ methane recovery as percentage of the influent TCOD, ${ }^{* *}$ : AnMBR comprising a UASB coupled to an external ultrafiltration membrane, ${ }^{* * *}$ : AnMBR comprising a UASB coupled to submerged membrane.

Commonly, membranes are integrated with anaerobic continuous stirred-tank reactor (CSTR). The key challenges with CSTR integrated with membranes are the membrane durability and fouling [44]. Using gas sparging as the fouling control strategy, it was reported that energy consumption of AnMBRs is 2485 to $12,275 \mathrm{~kJ} / \mathrm{m}^{3}$ of wastewater treated, which is alone higher than energy consumption in CAS-WWTPs [33]. Alternatively, UASB integration with membrane internally and externally was explored in pilot-scale level [45,46]. TCOD removal efficiencies as high as $87-90 \%$ were reported. In this study, despite being pre-settled, the used wastewater can be considered high-strength wastewater as the influent TCOD were averaged at $892-978 \mathrm{mg} / \mathrm{L}$. Moreover, energy consumption due to fouling is not solved.

Proposed in 2011, anaerobic fluidized bed membrane bioreactor (AFMBR) has shown outstanding performance in terms of COD removal and methane recovery with controlled fouling [47]. It consists of circular membrane inside anaerobic fluidized bed bioreactor with particulate media, commonly granular activated carbon (GAC). In the AFMBR, the fluidization of the particulate media lessens membrane fouling, which is called particulate sparging [2]. Using synthetic wastewater and at $35^{\circ} \mathrm{C}$, a two-stage anaerobic system of anaerobic fluidized bed bioreactor (AFBR) followed by AFMBR results in combined 
TCOD removal efficiencies of $99 \pm 1 \%$ (Table 1). In such configuration, the COD influent for the AFMBR was $59 \pm 31 \mathrm{mg}$-TCOD/L. For 120 days of operation, no membrane fouling was observed, which can be referred to the fluidization and limited incoming pCOD [47]. Energy expenditure in such system was as low as $208 \mathrm{~kJ} / \mathrm{m}^{3}$ of wastewater treated and counted mainly for the recirculation to maintain the GAC fluidization [2]. As a step further, single-stage AFMBR was compared with the two-stage system using synthetic wastewater with low COD concentration of $215 \pm 15 \mathrm{mg}-\mathrm{COD} / \mathrm{L}$, which is comparable to the primary treatment effluent. After more than 100 days of operation, it was concluded that single-stage system can efficiently operate with COD removal efficiency around 95\%, controlled fouling, HRTs as low as $2.2 \mathrm{~h}$, and temperature of $25^{\circ} \mathrm{C}$ [48].

Different outcomes were attained using real domestic wastewater, in which a TCOD removal efficiency of $76 \pm 3 \%$ and methane recovery of $45 \%$ at HRT of $8 \mathrm{~h}$ were obtained. Moreover, membrane fouling was less controlled due to the higher COD concentration $(320 \pm 44.15 \mathrm{mg}-\mathrm{COD} / \mathrm{L})$ and use of real domestic wastewater that contains higher fractions of pCOD. Yet, the GAC using reactors showed up to 3.3 times longer fouling cycle [49]. Even though COD fractionation was not reported in the previous study, such results imply that the use of single AFMBR is not effective at elevated concentrations of pCOD, similar to those expected in real wastewater. In agreement, two-stage AFBR-AFMBR pilot-scale system achieved combined COD removal efficiency more than $90 \%$ treating pre-settled wastewater with TCOD of 198-362 mg/L (Table 1) [42]. The methane recovery was reported equal to $50-55 \%$ considering $90 \%$ recovery of the dissolved methane. The energy consumption of the system was estimated to be $815 \mathrm{~kJ} / \mathrm{m}^{3}$ of wastewater treated, which can be potentially reduced by $50 \%$ by further optimization [42]. Accordingly, the energy recovered as electricity through methane per energy used was equal to $0.83 \mathrm{~kJ}$-electricity/ $\mathrm{kJ}$ used assuming $50 \%$ as the methane recovery and $280 \mathrm{mg}$-COD/L as the average influent. This can be potentially increased to $1.45 \mathrm{~kJ}$-electricity/kJ used. More recently, single and staged AFMBR capacity to handle high-strength and pCOD-rich municipal wastewater was evaluated. Despite being subjected to primary treatment, the TCOD and SCOD of the AFMBR influent in this study averaged at 806 and $70 \mathrm{mg} / \mathrm{L}$, respectively. At HRT of $2-3 \mathrm{~h}$ and $23^{\circ} \mathrm{C}$ as the average temperature, TCOD removal efficiency of $97 \%$ was obtained, as shown in Table 1 . Nonetheless, methane recovery was not reported in the study and membrane fouling was problematic at high membrane fluxes [50]. Interestingly, similar removal efficiency and fouling rates were observed in both systems, which contradict with the earlier findings. Here, it needs to be highlighted that the energy consumption of the AFBR represents only $7 \%$ of the total two-stage system energy consumption [42]. Hence, its low energy expenditure favors the use of AFBR prior to AFMBR in An-WRRF even if comparable results might be attained.

As an abridgment, AFMBR, single or staged with AFBR, found to be the most suitable membrane integrated high-rate anaerobic reactor to treat pre-settled wastewater. However, membrane fouling is still problematic but to lesser extent compared to other systems what makes AFMBR system more energy favorable, especially with medium/low strength wastewater [51,52]. Apart from membrane, anaerobic moving bed biofilm reactor (AMBBR) and AFBR were suggested to be employed without membrane addition. The rationale for such proposal is that TCOD removal efficiency of $55-90 \%$ can be sufficient if the nitrogen removal alternatives were considered. It was reported that methane recovery of $55-60 \%$ can be achieved in such systems. The holistic viewpoint of combining nutrients and carbon removal is prominent. However, further verification is required as the studies were performed using sugar-based synthetic wastewater and only in bench scale [43,53-55].

Dissolved methane (D-methane) recovery is a vital part of the An-WRRF or LEM concept to attain the methane recovery values in the discussion above. The expected D-methane concentration can be estimated using Henry's law. Accordingly, D-methane in anaerobic treatment effluent represents $45 \%$ of the potentially recovered methane at $30{ }^{\circ} \mathrm{C}$. This ratio is increased by $30 \%$ at temperature as low as $15{ }^{\circ} \mathrm{C}$ [56]. Undesirably, the actual values for the D-methane in effluent can be higher than the theoretical values, which is called supersaturation. Supersaturation is the ratio between the actual D-methane value and the estimated value based on Henry's Law [35]. Supersaturation is more 
observed in attached growth systems and blanket-based systems compared to CSTR systems due to the difference in the mixing regime. Using UASB, the supersaturation ratio can reach up to 6.9 even in temperature as high as $28^{\circ} \mathrm{C}$ [57]. This can be referred to as the poor mixing regimes that decline the mass transfer between the aqueous and gaseous phases. In favor of the LEM concept, D-methane in the effluent of different types of AnMBRs were found to be very close to the theoretical values. In AnMBRs, the attained supersaturation ratios range from 1 to 1.5, regardless of the temperature [35]. This can be referred to as the high gas or particulate (in AFMBR) recirculation, which results in better mixing regimes and higher mass transfer. When treating diluted wastewater, D-methane is more critical even at low supersaturation as up to $100 \%$ of the recovered methane can be dissolved $[42,58]$.

Diverse technologies have been suggested to recover the D-methane in the anaerobic effluents, including flash mixing, air stripping, headspace dissipation, and degassing membranes [35,59]. Air stripping technique was suggested as part of the LEM concept in which air bubbles induce the mass transfer of the D-methane [2]. It is beneficial due to its low energy requirements (only $180 \mathrm{~kJ} / \mathrm{m}^{3}$ of anaerobic effluent) [60]. However, it shows methane recovery as low as $30 \%$ at HRT as long as $8 \mathrm{~h}$, which will result in a large chamber volume [59]. Instead of air stripping, dissipation chamber showed methane recovery of $65-75 \%$ at similar HRT. In the dissipation chamber, D-methane transfer into the gaseous phase is stimulated by exhausting the gaseous headspace and induce D-methane transfer into the gaseous phase [59]. With the advantage of small reactors, the effluent can be subjected to high mixing speed to boost the mass transfer of methane from the liquid to the gaseous phase in flash mixing chamber. It can be implemented with small volume since the HRT can be very short. Using mixing speed of $800 \mathrm{rpm}$ and HRT of $11 \mathrm{~min}$, D-methane recovery of $90 \%$ was achieved; however, the energy investment was $432 \mathrm{~kJ} / \mathrm{m}^{3}$ of the effluent. This was higher than the energy recovered from the D-methane [43]. As another option, degassing membrane was suggested to replace the previous D-methane recovery techniques. It was reported that D-methane recovery as high as $98 \%$ is acquirable at very short HRT [61]. However, a very wide range of D-methane recovery $(10-98 \%)$ was reported using degassing membrane, which shows that further optimization is still needed [35,61]. Encouragingly, a more recent study found that degassing membranes are energy positive technology regardless of its recovery efficiency [62]. As such, the estimated energy consumption for such technology was reported to be very low ( $33 \mathrm{~kJ} / \mathrm{m}^{3}$ of effluent treated) [35]. Yet, it is worth pointing out that degassing membrane studies were performed using anaerobic effluent with very limited solids content to prevent membrane clogging [63]. Whereas, comparatively high solids content is expected in the anaerobic effluent in An-WRRFs. Generally, the area of D-methane still needs further investigations and optimization to achieve high methane recovery with limited energy investments and land requirements.

As a recapitulation, the liquid stream in the An-WRRF consists of primary clarifier, AFBR and AFMBR as the high rate anaerobic system, and D-methane recovery unit. Unlike An-WWTPs, solids stream exists in the An-WRRFs in which AD is needed to treat the primary sludge and recover methane. Such configuration was proposed based on a coherent rationale. The major objective of the primary treatment is to decrease the solids concentration so that the use of attached growth anaerobic reactor and membrane filtration becomes more feasible. However, membrane addition attenuates the unfavorable effects of the diluted COD concentrations caused by the primary treatment. Moreover, membrane employment allows extended SRTs and high solids/organics removal, which promotes process stability and efficiency. Additionally, it mitigates the temperature limitation reported in An-WWTPs. Whereas, D-methane recovery unit is added to maintain efficient COD capture and eliminate the negative environmental of releasing methane. Nonetheless, energy consumption in the An-WRRF is considerably higher than An-WWTPs. Such energy input is crucial to eliminate An-WWTPs downsides including low-temperature barrier, unstable and fluctuating contaminants removal efficiency, and limited recovery due to D-methane. Hence, the concept has become that An-WRRF has energy inputs comparable to CAS-WWTPs; however, it attains high energy recovery along with high and stable contaminant removal efficiency. As such, primary sludge handling may consume $290 \mathrm{~kJ} / \mathrm{m}^{3}$ treated [25], while AFBR-AFBMR system is estimated to use $900 \mathrm{~kJ} / \mathrm{m}^{3}$ 
treated [42]. In addition, $432 \mathrm{~kJ} / \mathrm{m}^{3}$ treated is consumed if flash mixing is employed to recover $90 \%$ of the D-methane [43]. In total, An-WRRF is expected to use $1622 \mathrm{~kJ}$ as electricity to treat $1 \mathrm{~m}^{3}$ of wastewater, which is comparable to CAS-WWTPs. However, nearly $4100 \mathrm{~kJ}$ as methane and $1430 \mathrm{~kJ}$ as electricity is attained in An-WRRF, which is 1.7 times higher than the average energy recovered from CAS-WWTPs, Figure 3. More importantly, An-WRRF produces $88 \%$ of its electricity requirements, which is equal to $47 \%$ using average scenario in CAS-WWTPs.

Finally, it should be noted that, to the best of our knowledge, AnMBR has not been applied to full-scale municipal wastewater plants. While the limited number of implemented AnMBR for industrial wastewater struggles with the financial burden of membrane fouling [64], only about ten reactors have been studied in pilot-scale [44]. Furthermore, the proposed combination of primary treatment followed by high-rate anaerobic reactor (either with or without membrane) has not been implemented in full scale. As a result, the performance proposed for An-WRRF technologies is still suspicious, especially in cold temperature, despite its promising results in pilot scale. Such concern is supported by the unstable performance observed in An-WWTPs [27]. Moreover, wide range of energy input and energy recovery efficiencies have been estimated/reported for AnMBRs and D-methane recovery units. For instance, the energy input for AnMBR ranges from 180 to $6000 \mathrm{~kJ} / \mathrm{m}^{3}$ wastewater treated according to Shin and Bae [44], whereas, in another study, it was reported as 110-20,000 kJ/ $\mathrm{m}^{3}$ wastewater treated [35], while AFBR/AFMBR system energy investments are reported as $180-820 \mathrm{~kJ} / \mathrm{m}^{3}$ [42,47]. Additionally, such estimations are theoretical and barely reinforced with actual measurements. Such barriers are expected to restrain the spread of An-WRRFs, particularly in cold temperatures. In addition, the vast majority of the existing WWTPs are designed as CAS-WWTPs, which add another barrier to the transition of the An-WRRFs.

\section{Conclusions}

Discussed in Section 2, four limitations have been suggested to hinder CAS-based WWTPs from being self-sufficient in terms of energy. In An-WWTPs, its basic idea addresses three out of the four core limitation in CAS-WWTPs as illustrated in Section 3. However, the process drawbacks, particularly in cold weather, necessitate further improvements in terms of its energy balance and applicability. Hence, the An-WRRF scheme was proposed based on a coherent rationale, argued in Section 4, in which primary treatment, membranes, and D-methane recovery units are added to the An-WWTPs scheme. As a result, high COD recovery and better performance in low temperatures were maintained and demonstrated in pilot scale. In the downside, the energy expenditures have not been notably decreased due to the use of membrane technology compared with CAS-WWTPs. In addition, biogas production is unavoidable, whereas some alternative WRRF schemes may be able to apply the VFA biorefinery concept if producing suitable sludge. Furthermore, the An-WRRF technology has been successfully implemented in pilot scale but not full scale. Finally, it is worth mentioning that for simplification, in this review, COD management has been reviewed apart from nutrients management. Nonetheless, a holistic perspective that includes all liquid stream processes shall be considered prior to WRRF selection.

Author Contributions: Conceptualization, A.A. and M.S.; writing-original draft preparation, A.A.; writing-review and editing, M.S.; visualization, A.A.; supervision, A.E.; funding acquisition, A.E. All authors have read and agreed to the published version of the manuscript.

Funding: This research was funded by Natural Sciences and Engineering Research Council of Canada (NSERC), grant number: RGPIN-2015-04805.

Conflicts of Interest: The authors declare that they have no conflicts of interest with regard to this work.

\section{References}

1. Liu, Y.Y.J.; Gu, J.; Liu, Y.Y.J. Energy Self-Sufficient Biological Municipal Wastewater Reclamation: Present Status, Challenges and Solutions Forward. Bioresour. Technol. 2018, 269, 513-519. [CrossRef] 
2. McCarty, P.L.; Bae, J.; Kim, J. Domestic Wastewater Treatment as a Net Energy Producer-Can This Be Achieved? Environ. Sci. Technol. 2011, 45, 7100-7106. [CrossRef]

3. Sancho, I.; Lopez-Palau, S.; Arespacochaga, N.; Cortina, J.L. New Concepts on Carbon Redirection in Wastewater Treatment Plants: A Review. Sci. Total Environ. 2019, 647, 1373-1384. [CrossRef]

4. Puyol, D.; Batstone, D.J.; Hülsen, T.; Astals, S.; Peces, M.; Krömer, J.O. Resource Recovery from Wastewater by Biological Technologies: Opportunities, Challenges, and Prospects. Front. Microbiol. 2017, 7, 1-23. [CrossRef]

5. Tang, J.; Zhang, C.; Shi, X.; Sun, J.; Cunningham, J.A. Municipal Wastewater Treatment Plants Coupled with Electrochemical, Biological and Bio-Electrochemical Technologies: Opportunities and Challenge Toward Energy Self-Sufficiency. J. Environ. Manag. 2019, 234, 396-403. [CrossRef]

6. Verstraete, W.; Van de Caveye, P.; Diamantis, V. Maximum Use of Resources Present in Domestic "Used Water". Bioresour. Technol. 2009, 100, 5537-5545. [CrossRef]

7. Foresti, E.; Zaiat, M.; Vallero, M. Anaerobic Processes as the Core Technology for Sustainable Domestic Wastewater Treatment: Consolidated Applications, New Trends, Perspectives, and Challenges. Rev. Environ. Sci. Biotechnol. 2006, 5, 3-19. [CrossRef]

8. Batstone, D.J.; Virdis, B. The Role of Anaerobic Digestion in the Emerging Energy Economy. Curr. Opin. Biotechnol. 2014, 27, 142-149. [CrossRef] [PubMed]

9. Sabliy, L.; Kuzminskiy, Y.; Zhukova, V.; Kozar, M.; Sobczuk, H. New Approaches in Biological Wastewater Treatment Aimed at Removal of Organic Matter and Nutrients. Ecol. Chem. Eng. S 2019, 26, 331-343. [CrossRef]

10. Geršl, M.; Kanduč, T.; Matýsek, D.; Šotnar, M.; Mareček, J. The Role of Mineral Phases in the Biogas Production Technology. Ecol. Chem. Eng. S 2018, 25, 51-59. [CrossRef]

11. Waclawek, S.; Grübel, K.; Silvestri, D.; Padil, V.V.T.; Waclawek, M.; Cerník, M.; Varma, R.S. Disintegration of Wastewater Activated Sludge (WAS) for Improved Biogas Production. Energies 2019, 12, 21. [CrossRef]

12. Alloul, A.; Ganigué, R.; Spiller, M.; Meerburg, F.; Cagnetta, C.; Rabaey, K.; Vlaeminck, S.E. Capture-Ferment-Upgrade: A Three-Step Approach for the Valorization of Sewage Organics as Commodities. Environ. Sci. Technol. 2018, 52, 6729-6742. [CrossRef] [PubMed]

13. von Sperling, M. Activated Sludge and Aerobic Biofilm Reactors; IWA Publishing: London, UK, 2007; Volume 5, ISBN 9781843391654.

14. Jimenez, J.A.; La Motta, E.J.; Parker, D.S. Kinetics of Removal of Particulate Chemical Oxygen Demand in the Activated-Sludge Process. Water Environ. Res. 2005, 77, 437-446. [CrossRef] [PubMed]

15. Jimenez, J.A.; La Motta, E.J.; Parker, D.S. Effect of Operational Parameters on the Removal of Particulate Chemical Oxygen Demand in the Activated Sludge Process. Water Environ. Res. 2007, 79, 984-990. [CrossRef]

16. Jimenez, J.; Miller, M.; Bott, C.; Murthy, S.; De Clippeleir, H.; Wett, B. High-Rate Activated Sludge System for Carbon Management-Evaluation of Crucial Process Mechanisms and Design Parameters. Water Res. 2015, 87, 476-482. [CrossRef] [PubMed]

17. Metcalf \& Eddy; Tchobanoglous, G.; Stensel, H.D.; Tsuchihashi, R.; Burton, F.L.; Abu-Orf, M.; Bowden, G.; Pfrang, W. Wastewater Engineering: Treatment and Resource Recovery, 5th ed.; McGraw Hill Education: New York, NY, USA, 2014; ISBN 0073401188.

18. Batstone, D.J.; Hülsen, T.; Mehta, C.M.; Keller, J. Platforms for Energy and Nutrient Recovery from Domestic Wastewater: A Review. Chemosphere 2015, 140, 2-11. [CrossRef]

19. Orhon, D. Evolution of the Activated Sludge Process: The First 50 Years. J. Chem. Technol. Biotechnol. 2015, 90, 608-640. [CrossRef]

20. AlSayed, A.; Fergala, A.; Eldyasti, A. Sustainable Biogas Mitigation and Value-Added Resources Recovery Using Methanotrophs Intergrated into Wastewater Treatment Plants. Rev. Environ. Sci. Biotechnol. 2018, 17, 351-393. [CrossRef]

21. Wan, J.; Gu, J.; Zhao, Q.; Liu, Y. COD Capture: A Feasible Option Towards Energy Self-Sufficient Domestic Wastewater Treatment. Sci. Rep. 2016, 6, 1-9. [CrossRef]

22. Pierie, F.; van Someren, C.E.J.; Benders, R.M.J.; Bekkering, J.; van Gemert, W.J.T.; Moll, H.C. Environmental and Energy System Analysis of Bio-Methane Production Pathways: A Comparison between Feedstocks and Process Optimizations. Appl. Energy 2015, 160, 456-466. [CrossRef]

23. von Sperling, M. Basic Principles of Wastewater Treatment; IWA Publishing: London, UK, 2007; Volume 2, ISBN 9781843391623. 
24. Kleerebezem, R.; Joosse, B.; Rozendal, R.; van Loosdrecht, M.C.M. Anaerobic Digestion Without Biogas? Rev. Environ. Sci. Biotechnol. 2015, 14,787-801. [CrossRef]

25. Gu, Y.; Li, Y.; Li, X.; Luo, P.; Wang, H.; Robinson, Z.P.; Wang, X.; Wu, J.; Li, F. The Feasibility and Challenges of Energy Self-Sufficient Wastewater Treatment Plants. Appl. Energy 2017, 204, 1463-1475. [CrossRef]

26. Lettinga, G.; van Velsen, A.F.M.; Hobma, S.W.; de Zeeuw, W.; Klapwijk, A. Use of the Upflow Sludge Blanket (USB) Reactor Concept For Biological Wastewater Treatment, Especially for Anaerobic Treatment. Biotechnol. Bioeng. 1980, 22, 699-734. [CrossRef]

27. Chernicharo, C.A.L.; van Lier, J.B.; Noyola, A.; Bressani Ribeiro, T.B. Anaerobic Sewage Treatment: State of the Art, Constraints and Challenges. Rev. Environ. Sci. Bio/Technol. 2015, 14, 649-679. [CrossRef]

28. Foresti, E. Anaerobic Treatment of Domestic Sewage: Established Technologies and Perspectives. Water Sci. Technol. 2002, 45, 181-186. [CrossRef] [PubMed]

29. Shoener, B.D.; Bradley, I.M.; Cusick, R.D.; Guest, J.S. Energy Positive Domestic Wastewater Treatment: The Roles of Anaerobic and Phototrophic Technologies. Environ. Sci. Process. Impacts 2014, 16, 1204-1222. [CrossRef]

30. Chong, S.; Sen, T.K.; Kayaalp, A.; Ang, H.M. The Performance Enhancements of Upflow Anaerobic Sludge Blanket (UASB) Reactors for Domestic Sludge Treatment - A State-of-the-Art Review. Water Res. 2012, 46, 3434-3470. [CrossRef]

31. Jimenez, J.A.; Bethke, L.; Rattier, M.; Hu, S.; Santoro, D.; Sarathy, S.; Filmore, L.; Willis, J.; Keller, J.; Batstone, D. Development of a Mainstream Anaerobic Treatment Process Using a Hybrid UASB-Micro Sieve System. Proc. Water Environ. Fed. 2016, 2016, 2686-2695. [CrossRef]

32. Seghezzo, L.; Zeeman, G.; Van Lier, J.B.; Hamelers, H.V.M.V.M.; Lettinga, G. A Review: The Anaerobic Treatment of Sewage in UASB and EGSB Reactors. Bioresour. Technol. 1998, 65, 175-190. [CrossRef]

33. Smith, A.L.; Stadler, L.B.; Love, N.G.; Skerlos, S.J.; Raskin, L. Perspectives on Anaerobic Membrane Bioreactor Treatment of Domestic Wastewater: A Critical Review. Bioresour. Technol. 2012, 122, 149-159. [CrossRef]

34. Chernicharo, C.A.L. Post-Treatment Options for the Anaerobic Treatment of Domestic Wastewater. Rev. Environ. Sci. Bio/Technol. 2006, 5, 73-92. [CrossRef]

35. Crone, B.C.; Garland, J.L.; Sorial, G.A.; Vane, L.M. Significance of Dissolved Methane in Effluents of Anaerobically Treated Low Strength Wastewater and Potential for Recovery as an Energy Product: A Review. Water Res. 2016, 104, 520-531. [CrossRef] [PubMed]

36. Lettinga, G.; Rebac, S.; Zeeman, G. Challenge of Psychrophilic Anaerobic Wastewater Treatment. Trends Biotechnol. 2001, 19, 363-370. [CrossRef]

37. Lettinga, G. Anaerobic Digestion and Wastewater Treatment Systems. Antonie Van Leeuwenhoek 1995, 67, 3-28. [CrossRef] [PubMed]

38. Aiyuk, S.; Odonkor, P.; Theko, N.; van Haandel, A.; Verstraete, W. Technical Problems Ensuing from UASB Reactor Application in Domestic Wastewater Treatment without Pre-Treatment. Int. J. Environ. Sci. Dev. 2010, 392-398. [CrossRef]

39. van der Last, A.R.M.; Lettinga, G. Anaerobic Treatment of Domestic Sewage under Moderate Climatic (Dutch) Conditions Using Upflow Reactors at Increased Superficial Velocities. Water Sci. Technol. 1992, 25, 167-178. [CrossRef]

40. Aiyuk, S.; Amoako, J.; Raskin, L.; van Haandel, A.; Verstraete, W. Removal of Carbon and Nutrients from Domestic Wastewater Using a Low Investment, Integrated Treatment Concept. Water Res. 2004, 38, 3031-3042. [CrossRef]

41. Álvarez, J.A.; Armstrong, E.; Gómez, M.; Soto, M. Anaerobic Treatment of Low-Strength Municipal Wastewater by a Two-Stage Pilot Plant Under Psychrophilic Conditions. Bioresour. Technol. 2008, 99, 7051-7062. [CrossRef]

42. Shin, C.; McCarty, P.L.; Kim, J.; Bae, J. Pilot-Scale Temperate-Climate Treatment of Domestic Wastewater with a Staged Anaerobic Fluidized Membrane Bioreactor (SAF-MBR). Bioresour. Technol. 2014, 159, 95-103. [CrossRef]

43. Gu, J.; Xu, G.; Liu, Y. An Integrated AMBBR and IFAS-SBR Process for Municipal Wastewater Treatment Towards Enhanced Energy Recovery, Reduced Energy Consumption and Sludge Production. Water Res. 2017, 110, 262-269. [CrossRef]

44. Shin, C.; Bae, J. Current Status of the Pilot-Scale Anaerobic Membrane Bioreactor Treatments of Domestic Wastewaters: A Critical Review. Bioresour. Technol. 2018, 247, 1038-1046. [CrossRef] [PubMed] 
45. Gouveia, J.; Plaza, F.; Garralon, G.; Fdz-Polanco, F.; Peña, M. Long-Term Operation of a Pilot Scale Anaerobic Membrane Bioreactor (AnMBR) for the Treatment of Municipal Wastewater under Psychrophilic Conditions. Bioresour. Technol. 2015, 185, 225-233. [CrossRef] [PubMed]

46. Gouveia, J.; Plaza, F.; Garralon, G.; Fdz-Polanco, F.; Peña, M. A Novel Configuration for an Anaerobic Submerged Membrane Bioreactor (AnSMBR). Long-Term Treatment of Municipal Wastewater under Psychrophilic Conditions. Bioresour. Technol. 2015, 198, 510-519. [CrossRef] [PubMed]

47. Kim, J.; Kim, K.; Ye, H.; Lee, E.; Shin, C.; McCarty, P.L.; Bae, J. Anaerobic Fluidized Bed Membrane Bioreactor for Wastewater Treatment. Environ. Sci. Technol. 2011, 45, 576-581. [CrossRef] [PubMed]

48. Bae, J.; Shin, C.; Lee, E.; Kim, J.; McCarty, P.L. Anaerobic Treatment of Low-Strength Wastewater: A Comparison between Single and Staged Anaerobic Fluidized Bed Membrane Bioreactors. Bioresour. Technol. 2014, 165, 75-80. [CrossRef]

49. Gao, D.-W.; Hu, Q.; Yao, C.; Ren, N.-Q.; Wu, W.-M. Integrated Anaerobic Fluidized-Bed Membrane Bioreactor for Domestic Wastewater Treatment. Chem. Eng. J. 2014, 240, 362-368. [CrossRef]

50. Wu, B.; Li, Y.; Lim, W.; Lee, S.L.; Guo, Q.; Fane, A.G.; Liu, Y. Single-Stage Versus Two-Stage Anaerobic Fluidized Bed Bioreactors in Treating Municipal Wastewater: Performance, Foulant Characteristics, and Microbial Community. Chemosphere 2017, 171, 158-167. [CrossRef]

51. Evans, P.J.; Bae, J.; Shin, C.; Lim, K.; McCarty, P.L.; Parameswaran, P.; Penfield, T.; Schmidt, B. Pilot-Scale Comparison of Gas-Sparged and GAC-Fluidized Anaerobic Membrane Bioreactors Treating Domestic Wastewater. Proc. Water Environ. Fed. 2017, 2017, 5446-5455. [CrossRef]

52. Shin, C.; Kim, K.; McCarty, P.L.; Kim, J.; Bae, J. Integrity of Hollow-Fiber Membranes in a Pilot-Scale Anaerobic Fluidized Membrane Bioreactor (AFMBR) after Two-Years of Operation. Sep. Purif. Technol. 2016, 162, 101-105. [CrossRef]

53. Gu, J.; Yang, Q.; Liu, Y. Mainstream Anammox in a Novel A-2B Process for Energy-Efficient Municipal Wastewater Treatment with Minimized Sludge Production. Water Res. 2018, 138, 1-6. [CrossRef]

54. Xu, G.; Wang, H.; Gu, J.; Shen, N.; Qiu, Z.; Zhou, Y.; Liu, Y. A Novel A-B Process For Enhanced Biological Nutrient Removal in Municipal Wastewater Reclamation. Chemosphere 2017, 189, 39-45. [CrossRef] [PubMed]

55. Gu, J.; Yang, Q.; Liu, Y. A Novel Strategy Towards Sustainable and Stable Nitritation-Denitritation in an A-B Process for Mainstream Municipal Wastewater Treatment. Chemosphere 2018, 193, 921-927. [CrossRef] [PubMed]

56. Liu, Z.; Yin, H.; Dang, Z.; Liu, Y. Dissolved Methane: A Hurdle for Anaerobic Treatment of Municipal Wastewater. Environ. Sci. Technol. 2014, 48, 889-890. [CrossRef]

57. Singh, K.S.; Harada, H.; Viraraghavan, T. Low-Strength Wastewater Treatment by a UASB Reactor. Bioresour. Technol. 1996, 55, 187-194. [CrossRef]

58. Bandara, W.M.K.R.T.W.; Kindaichi, T.; Satoh, H.; Sasakawa, M.; Nakahara, Y.; Takahashi, M.; Okabe, S. Anaerobic Treatment of Municipal Wastewater at Ambient Temperature: Analysis of Archaeal Community Structure and Recovery of Dissolved Methane. Water Res. 2012, 46, 5756-5764. [CrossRef] [PubMed]

59. Glória, R.M.; Motta, T.M.; Silva, P.V.O.; da Costa, P.; Brandt, E.M.F.; Souza, C.L.; Chernicharo, C.A.L.; Glória, R.M.; Motta, T.M.; Silva, P.V.O.; et al. Stripping and Dissipation Techniques for the Removal of Dissolved Gases from Anaerobic Effluents. Braz. J. Chem. Eng. 2016, 33, 713-721. [CrossRef]

60. Seib, M.D.; Berg, K.J.; Zitomer, D.H. Reduced Energy Demand for Municipal Wastewater Recovery Using an Anaerobic Floating Filter Membrane Bioreactor. Environ. Sci. Water Res. Technol. 2016, 2, 290-297. [CrossRef]

61. Henares, M.; Izquierdo, M.; Penya-Roja, J.M.; Martínez-Soria, V. Comparative Study of Degassing Membrane Modules for the Removal of Methane from Expanded Granular Sludge Bed Anaerobic Reactor Effluent. Sep. Purif. Technol. 2016, 170, 22-29. [CrossRef]

62. Henares, M.; Izquierdo, M.; Marzal, P.; Martínez-Soria, V. Demethanization of Aqueous Anaerobic Effluents Using a Polydimethylsiloxane Membrane Module: Mass Transfer, Fouling and Energy Analysis. Sep. Purif. Technol. 2017, 186, 10-19. [CrossRef]

63. Cookney, J.; Mcleod, A.; Mathioudakis, V.; Ncube, P.; Soares, A.; Jefferson, B.; McAdam, E.J. Dissolved Methane Recovery from Anaerobic Effluents Using Hollow Fibre Membrane Contactors. J. Memb. Sci. 2016, 502, 141-150. [CrossRef]

64. van Lier, J.B.; van der Zee, F.P.; Frijters, C.T.M.J.; Ersahin, M.E. Celebrating 40 Years Anaerobic Sludge Bed Reactors for Industrial Wastewater Treatment. Rev. Environ. Sci. Bio/Technol. 2015, 14, 681-702. [CrossRef] 
(C) 2020 by the authors. Licensee MDPI, Basel, Switzerland. This article is an open access article distributed under the terms and conditions of the Creative Commons Attribution (CC BY) license (http://creativecommons.org/licenses/by/4.0/). 